\title{
MIGRATION AND URBAN SCHISTOSOMIASIS. THE CASE OF SÃO LOURENÇO DA MATA, NORTHEAST OF BRAZIL
}

\author{
Ricardo Arraes de Alencar XIMENES(1), Brian SOUTHGATE(2), Peter G. SMITH(2) \& Leonardo GUIMARÃES NETO(3)
}

\begin{abstract}
SUMMARY
A population-based case-control design was used to investigate the association between migration, urbanisation and schistosomiasis in the Metropolitan Region of Recife, Northeast of Brazil. 1022 cases and 994 controls, aged 10 to 25, were selected. The natives and the migrants who come from endemic areas have a similar risk of infection. On the other hand, the risk of infection of migrants from nonendemic areas seems to be related with the time elapsed since their arrival in São Lourenço da Mata; those who have been living in that urban area for 5 or more years have a risk of infection similar to that of the natives.

Those arriving in the metropolitan region of Recife mostly emigrate from "zona da mata" and "zona do agreste" in the state of Pernambuco. Due to the changes in the sugar agro-industry and to the increase in the area used for cattle grazing these workers were driven to villages and cities. The pattern of urbanisation created the conditions for the establishment of foci of transmission in São Lourenço da Mata.
\end{abstract}

KEYWORDS: Migration, Urban schistosomiasis.

\section{INTRODUCTION}

Schistosomiasis continues to be a major public health problem. Schistosoma mansoni is widespread, infecting people in Africa, eastern Mediterranean, South America and the Caribbean. In Brazil there is a vast endemic area extending from the State of Rio Grande do Norte to the state of Minas Gerais and comprising the states of Paraiba, Pernambuco, Alagoas, Sergipe and Bahia. In addition, focal transmission occurs in almost every state in the country. The major clinical manifestations occur in less than $10 \%$ of the infected population. Enlargement of the liver, spleen and oesophageal varices are related to the portal hypertension caused by liver fibrosis (Symmers' fibrosis). The disease may evolve depending on the intensity of infection, and several other factors, leading to upper gastrointestinal bleeding from varices, ascites and anaemia.

Population movements have led to an important increase in the spread of schistosomiasis in Africa and in Brazil and may also interfere with the efficacy of control measures adopted $4-7,10,15,18,20-22,26,30,34$. Schistosomiasis is no longer a rural disease. It has been described not only in small villages where the population still survives mainly on agricultural activities, but also in industrialised urban areas ${ }^{5,8,9,11,19,23,24,27,31}$.

The expansion of schistosomiasis may be analysed in the light of a structural and historical causation ${ }^{3,36}$. In this paper we discuss the association between migration, urbanisation and schistosomiasis, in the Metropolitan Region of Recife, Northeast of Brazil. In two other articles we comment on two other aspects of the social network in which schistosomiasis is inserted ${ }^{36}$.

São Lourenço da Mata belongs to the Metropolitan Region of Recife and it is situated $20 \mathrm{~km}$ away from the centre of the nuclear city. To understand the population movements towards São Lourenço da Mata it is necessary first to place it in the contexts of the Metropolitan Region of Recife and of the Northeast of Brazil. Important changes have occurred in the economy of this area since the 1960s. There has been a development of industry and of commerce associated with an increasing rate of urbanisation. The role of migration in the population growth of Recife has varied over time but it has always been important. However, in the sixties a new phenomenon was observed; the saturation of the nuclear city balanced, to some extent, by the enlargement of other "municipios" within the metropolitan area.

Those arriving in the metropolitan region of Recife mostly emigrate from "zona da mata" and "zona do agreste" in the state of Pernambuco. In "zona da mata" the development of the sugar agro-industry has led to the creation of large land estates and monoculture. This strongly affected migration. As those industries expanded into the lands formerly cultivated

(1) Departamento de Medicina Tropical, Universidade Federal de Pernambuco, Recife, PE, Brasil.

(2) Department of Infectious and Tropical Diseases, London School of Hygiene and Tropical Medicine,University of London, UK.

(3) Departamento de Economia, Universidade Federal da Paraiba, PB, Brasil.

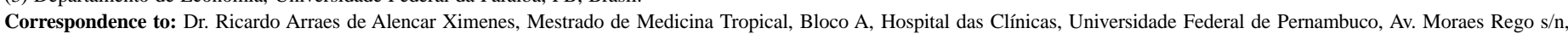
Cidade Universitaria, 50670-420 Recife, PE, Brazil. Tel/Fax: 005581-2718527/2718514. E-mail: rximenes@elogica.com.br 


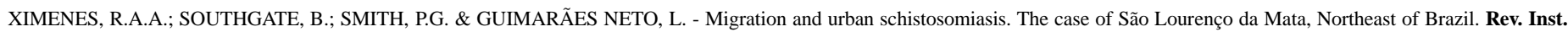
Med. trop. S. Paulo, 42(4): 209-217, 2000.

by the agricultural workers these workers were driven to the villages and cities in the neighbourhood or to a more distant area such as Recife ${ }^{1}$.

"Zona do Agreste" has become a region of cattle grazing as well as of commercial and subsistence crops (corn, beans, cassava, cotton, coffee, etc) and small rather than large land estates were set up more frequently. However, from the 1960s onwards there was a marked increase in the area used for cattle grazing. Not being able to bring land into cultivation the agricultural workers have become redundant and many left their place of origin and some moved to Recife ${ }^{1,2}$.

"Zona da mata" is an endemic area for schistosomiasis the prevalence of infection varying largely from one "Município" to the other. The prevalence in school children aged 7 to 14 years, living in the Capibaribe River Basin, the most important in the area, remained around $17 \%$ from 1985 to 1991 , according to the data given by the Superitendence of Public Health Campaigns (SUCAM). In the urban São Lourenço da Mata, we found a prevalence of schistosomiasis, in the age-group 10-25 years, of $25.8 \%{ }^{36}$. In "Zona do Agreste" scattered foci are found. Population movements, being directed to urban areas, will affect the risk of infection of the native urban population if transmission takes place in the cities.

\section{MATERIAL AND METHODS}

\section{General characteristics of the study population and area}

The Municipio of São Lourenço da Mata lies in the tropical rain forest region along the coast of Northeast Brazil. It was estimated that the "Distrito" of São Lourenço da Mata would have, in 1986, an urban population of 50124 inhabitants and a rural population of 14176. It has a natural stream system along the Capibaribe River. The annual temperature of the region averages $27^{\circ} \mathrm{C}$ and its climate is hot and moist. There is a marked rainfall cycle with a rainy season from March to August and about $80 \%$ of the total precipitation falls during this period. The remainder of the year forms the dry season, with only occasional rain. The average annual rainfall is $1500 \mathrm{~mm}$. Schistosomiasis is endemic in the area and the local intermediate host is Biomphalaria straminea.

\section{The study design and the sampling procedure}

A population-based case-control design was used to investigate the association between migration and schistosomiasis.

A cross-sectional study was carried out to measure the prevalence of schistosomiasis in São Lourenço da Mata in the age-group 10-25 years, to estimate the socio-economic characteristics of households with individuals aged 10-25 years and to investigate the association between the socio-economic factors and schistosomiasis ${ }^{36}$.

For the cross-sectional study, 2864 households were selected through a multi-stage random sampling procedure. The urban population of São Lourenço da Mata was stratified by area of residence and a random sample of households was selected within each stratum (area), keeping the same sampling fraction for every stratum. For the case-control investigation we included all cases living in these houses and in the age group described. To select the controls we drew a subsample of 939 households out of the whole sample of 2864, using stratified random sampling with a uniform sampling fraction. Using this sampling fraction we expected to include about 1200 persons without schistosomiasis infection (assuming about $25 \%$ of the population aged 10-25 years was infected.

Regarding the age-group, the choice to work with a sample of the population aged from 10 to 25 was made to meet two main concerns. First of all it should be born in mind that the prevalence of infection in most areas endemic for $S$. mansoni is generally greatest in the 10-24 year old age-group ${ }^{35}$. Second, the population that moved to live in the Metropolitan Region of Recife (immigrants) is very young, mostly in the age-group 10-14 years and 15-19 years ${ }^{25}$.

\section{Data collection and analysis}

A questionnaire was applied to those in the age group 10 to 25 years to explore the relation between migration and schistosomiasis. For the diagnosis of schistosomiasis the Kato method ${ }^{16}$ as modified by KATZ et al. (1972) was used. Two slides were prepared from each specimen and the number of eggs counted on the slide was multiplied by a correction factor, 24, to obtain the number of eggs per gram of faeces. The result we used was the mean value between the two readings. In the analysis to define "migrants" we took account of the place of birth and the place where the individual lived. In the metropolitan region of Recife the urban areas are very close to each other and sometimes women decide to give birth in the next city because of better health services or because of the presence of relatives and they return to their own area after the birth. So we regarded as natives those who were born either in São Lourenço da Mata or elsewhere but went to live there before the end of their second year of life. Conversely, migrants were defined to be those not born in São Lourenço da Mata who moved to that urban area after the age of two years. The data collection was done in 1988 .

As the Metropolitan Region of Recife as a whole, and São Lourenço da Mata in particular, are areas into which there has been substantial migration and as the presence of the intermediate host in this urban area creates conditions for the perpetuation of transmission, our first interest was to assess if there were differences in the risk of being infected between migrants and nonmigrants. If it were found to be true it would be necessary to further examine the risk of infection in different groups of migrants. Migrants are expected to vary in several characteristics, some of which are of greater interest to our study and may be related to the risk of schistosomiasis infection. They may differ in their place of origin, having moved from urban or rural areas or from endemic (for schistosomiasis) or nonendemic regions; length of residence in São Lourenço da Mata as well as the age they immigrated may affect comparisons within the group of migrants or between migrants and natives. These factors were considered in our analysis.

A logistic regression was used to investigate the relationship between schistosomiasis and migration. For all levels of each exposure we estimated the odds-ratio, confidence intervals and $\mathrm{p}$ value and we used the likelihood ratio test to test the hypothesis of no association between the exposure and the disease. To model the joint effect of several exposures we adopted a step-down regression procedure. That is, we introduced all independent variables and we dropped them one by one, based on the likelihood ratio test statistics.

For basic data handling we used the Statistical Analysis System SAS, a statistical package for data analysis. To perform the logistic 
regression analysis we used the statistical package for Generalised Interactive Modelling (GLIM) which estimates the logistic parameters through a maximum likelihood approach.

\section{RESULTS}

\section{General characteristics of the study population}

2016 subjects were selected, 1022 cases and 994 controls.

In the group of natives there were 1239 individuals, 567 infected and 672 uninfected whereas the group of migrants was composed of 775 subjects, 349 infected and 427 uninfected; for 1 individual we did not have enough information to classify him/her as native or migrant.

448 individuals were assigned to the group of migrants from endemic areas, 243 infected and 205 not infected; 327 subjects were allocated to the group of migrants from nonendemic areas, 105 infected and 222 uninfected.

\section{Migration and schistosomiasis}

The risk of schistosomiasis infection in migrants was about 1.4 times higher in natives than in migrants $(\mathrm{p}<0.001)$ (Table 1$)$.

No significant differences were found in risk between different agegroups but females were at lower risk (Table 1). Similar prevalence levels were found in those with and without history of treatment for schistosomiasis (Table 1).

Table 1

Estimated odds ratio, confidence intervals and p-values for schistosomiasis according to the place of origin, to the age-group, to the sex and to the antischistosomiasis treatment

\begin{tabular}{lcc}
\hline Variable $\quad$ Odds ratio & $\begin{array}{c}\text { 95\% Confidence } \\
\text { Interval }\end{array}$ & $\begin{array}{c}\text { p-value } \\
\text { (two-sided) }\end{array}$ \\
\hline
\end{tabular}

\begin{tabular}{lllll}
\hline $\begin{array}{l}\text { Place of origin } \\
\text { Natives }\end{array}$ & $1.00^{\mathrm{b}}$ & & & \\
$\begin{array}{l}\text { Migrants } \\
\text { Age-group }\end{array}$ & 0.69 & 0.58 & 0.83 & $\mathrm{p}<0.001$ \\
10 to 14 years & $1.00^{\mathrm{b}}$ & & & \\
15 to 19 years & 1.21 & 0.99 & 1.49 & N.S. \\
20 to 25 years & 0.94 & 0.76 & 1.17 & N.S. \\
Sex & & & & \\
Male & $1.00^{\mathrm{b}}$ & & & \\
$\begin{array}{l}\text { Female } \\
\text { Antischistosomiasis }\end{array}$ & 0.44 & 0.37 & 0.53 & $\mathrm{p}<0.001$ \\
treatment & & & & \\
Treated & $1.00^{\mathrm{b}}$ & & & \\
Untreated & 1.02 & 0.17 & 6.32 & N.S. \\
\hline
\end{tabular}

a $($ missing value $=1) ;{ }^{b}$ reference; ${ }^{c}($ missing values $=5)$

When both sex and place of origin were included in multivariate analyses, the odds ratios were not materially changed (data not shown).
We explored different aspects of the association of schistosomiasis and place of origin by comparing different subgroups within the native and migrant population. Among the natives we examined the association between the infection and age, sex, treatment for schistosomiasis and place where the subjects lived.

There was no association evident between schistosomiasis and agegroup (Table 2). The risk of being infected was approximately 2 times greater for males (Table 2). The odds ratios for the association between schistosomiasis and antischistosomiasis treatment are given on Table 2. When the native population was considered alone there was evidence of an enhancement of risk for those who had not been treated. Among natives the risk of infection for those who lived some time out of São Lourenço da Mata was similar to that of those who had lived there all their lives (Table 2).

\section{Table 2}

Odds ratios, confidence intervals and p-values for schistosomiasis, in the native population of São Lourenço da Mata, according to the age-group, to the sex, to the antischistosomiasis treatment and to the place where they lived

\begin{tabular}{|c|c|c|c|}
\hline Variable & Odds ratio & $\begin{array}{l}\text { 95\% Confidence } \\
\text { Interval }\end{array}$ & $\begin{array}{c}\text { p-value } \\
\text { (two-sided) }\end{array}$ \\
\hline
\end{tabular}

\begin{tabular}{lllll}
\hline Age-group & & & & \\
$10-14$ years & $1.00^{\mathrm{a}}$ & & & \\
$15-19$ years & 1.09 & 0.84 & 3.08 & N.S. \\
$20-25$ years & 1.02 & 0.77 & 1.36 & N.S. \\
Sex & & & & \\
Male & $1.00^{\mathrm{a}}$ & & & \\
Female & 0.46 & 0.37 & 0.58 & $\mathrm{p}<0.001$
\end{tabular}

$\begin{array}{lc}\text { Antischistosomiasis } & \text { Treatment } \\ \text { Treated } & 1.00^{\mathrm{a}} \\ \text { Untreated } & 1.52\end{array}$

\section{Place where lived}

Lived some

time out of SLM

Lived in SLM

all their lives

$1.00^{\mathrm{a}}$

$\begin{array}{lllll}\text { all their lives } & 1.10 & 0.81 & 1.51 & \text { N.S. }\end{array}$

${ }^{\mathrm{a}}$ reference

Migrants were categorised according to the place they had lived before moving to São Lourenço da Mata into those who before immigrating had lived in an area endemic for schistosomiasis and those who had never lived in an endemic area. The association of this variable with schistosomiasis was statistically significant (Table 3). The risk of being infected was 2.5 times larger for those who had lived in an endemic area.

The age and sex-adjusted odds ratio for the association between schistosomiasis and the place where the migrant lived (data not shown) was similar to that obtained before adjustment (Table 3).

The effect of length of time the individuals had been living in São Lourenço da Mata could vary according to their place of origin and we found that the risk of infection was related to having lived or not in an 


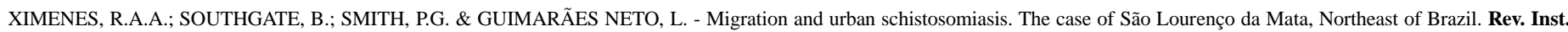
Med. trop. S. Paulo, 42(4): 209-217, 2000.

Table 3

Odds ratios, confidence intervals and p-values for schistosomiasis according to the place the migrants had lived

\begin{tabular}{cc}
\hline Variable & Odds ratio \\
& $\begin{array}{c}95 \% \text { Confidence } \\
\text { Interval }\end{array}$
\end{tabular}

\section{Migrants from}

endemic area

Migrants from

Nonendemic area $\quad 0.40 \quad 0.30 \quad 0.54$

Likelihood ratio statistic on 1 d.f. $=38, \mathrm{p}<0.001$

${ }^{\mathrm{a}}$ reference

endemic area. In such situation, where the effect of one variable may vary according to the level of the other, i.e., where there may be interaction, it is better to examine the effect of length of time separately for the 2 groups. We stratified the migrants in 2 strata according to whether the individuals had or not lived in an endemic area. As the stratum specific odds ratio could differ not only in relation to timing variables (age at arrival, time living) but also regarding other factors under study, we assessed, in each group, the risk of infection for each of the factors under investigation.

Table 4 shows the results for the association between schistosomiasis and age-group. There was no statistically significant association between schistosomiasis and age-group for the migrants from endemic areas, a finding similar to the one which had been obtained for the natives. However, in the group of migrants from nonendemic areas the association was statistically significant. For those aged 15 to 19 years there was an increased risk but the confidence interval included 1 . Those aged 20 to 25 years had a significantly lower risk of infection.

Table 4

Odds ratios, confidence intervals and p-values for schistosomiasis according to the age-group in the migrant population from endemic and nonendemic areas

\begin{tabular}{|c|c|c|c|}
\hline Variable & Odds ratio & $\begin{array}{l}\text { 95\% Confidence } \\
\text { Interval }\end{array}$ & $\begin{array}{c}\text { p-value } \\
\text { (two-sided) }\end{array}$ \\
\hline
\end{tabular}

\section{AGE-GROUP}

\section{Migrants from endemic area}

10 - 14 years $\quad 1.00^{\mathrm{a}}$

15 - 19 years $\quad 1.44$

20 - 25 years $\quad 1.09$

$\begin{array}{ll}0.87 & 2.30\end{array}$

$0.68 \quad 1.72$

Likelihood ratio statistic on 2 d.f. $=2.63, \mathrm{p}>0.10$

\section{Migrants from nonendemic area}

$\begin{array}{llllc}10-14 \text { years } & 1.00^{\mathrm{a}} & & & \\ 15-19 \text { years } & 1.40 & 0.82 & 2.40 & \text { N.S. } \\ 20-25 \text { years } & 0.54 & 0.29 & 0.99 & \mathrm{p}<0.05\end{array}$

Likelihood ratio statistic on 2 d.f. $=9.58,0.001<\mathrm{p}<0.01$

areference
The association between sex and infection was statistically significant in both groups, the estimated odds ratio for females being significantly reduced in both cases (Table 5).

Table 5

Odds ratios, confidence intervals and p-values for schistosomiasis according to the sex, for the migrants from endemic and nonendemic areas

\begin{tabular}{cc}
\hline Variable Odds ratio & $\begin{array}{c}95 \% \text { Confidence } \\
\text { Interval }\end{array}$ \\
\hline
\end{tabular}

SEX

Migrants from endemic area
$\begin{array}{lccc}\text { Male } & 1.00^{\mathrm{a}} & & \\ \text { Female } & 0.43 & 0.29 & 0.62 \\ \text { Likelihood ratio statistic }= & 19.84, \text { on } 1 \text { d.f., } \mathrm{p}<0.001\end{array}$

Migrants from nonendemic areas

$\begin{array}{llll}\text { Male } & 1.00^{\mathrm{a}} & & \\ \text { Female } & 0.30 & 0.18 & 0.50\end{array}$

Likelihood ratio statistic $=23.09$, on 1 d.f., $\mathrm{p}<0.001$

${ }^{a}$ reference

The magnitude of the reductions among females were similar to that observed within the group of natives.

The risk of infection associated with antischistosomiasis treatment is given on Table 6 and those on age at arrival and time living in São Lourenço da Mata are shown in Tables 7 and 8.

For both groups of migrants there was no association between infection and treatment for schistosomiasis.

Table 6

Odds ratios, confidence intervals and p-values for schistosomiasis according to the anti schistosomiasis treatment, for the group of migrants from endemic and nonendemic areas

\begin{tabular}{cc}
\hline Variable $\quad$ Odds ratio & $\begin{array}{c}\text { 95\% Confidence } \\
\text { Interval }\end{array}$
\end{tabular}

\section{TREATMENT FOR}

\section{SCHISTOSOMIASIS}

\begin{tabular}{|c|c|c|c|}
\hline \multicolumn{4}{|c|}{ Migrants from endemic area } \\
\hline Treated & $1.00^{\mathrm{a}}$ & & \\
\hline Untreated & 1.06 & 0.73 & 1.54 \\
\hline
\end{tabular}

Migrants from nonendemic area

$\begin{array}{lccc}\text { Treated } & 1.00^{\mathrm{a}} & & \\ \text { Untreated } & 0.64 & 0.40 & 1.02 \\ \text { Likelihood ratio statistic }= & =3.55, \text { on } 1 \text { d.f., } & 0.05<\mathrm{p}<0.10\end{array}$

ratio statistic $=3.55$, on 1 d.f., $0.05<p<0.10$

${ }^{a}$ reference 
For those migrants who had lived in an endemic area, neither age at arrival nor time living in São Lourenço da Mata were significantly associated with schistosomiasis.

For those migrants who had migrated from a nonendemic area schistosomiasis was found to be significantly associated with both age at arrival and time living in São Lourenço da Mata. Concerning the age at arrival there was a reduction of risk for all age-groups when compared to those who migrated in the age-group 2 to 4 years. Regarding the time living in São Lourenço da Mata those residing in that city for 5 to 9 years or for 10 or more years experienced a significantly greater risk, the magnitude of the estimates being similar in both levels.

As we studied persons aged 10 to 25 years those who arrived in São Lourenço da Mata in the age-group 20 to 25 years could not be living there for more than 5 years, as those who arrived when aged 15 to 19 years could not be living there for more than 10 years. When adjusting one variable for the other (Table 9) this intercorrelation leads to multicollinearity and it is not possible to segregate the effects of the two factors. When putting both factors in a model, dropping time living in São Lourenço da Mata from the model, the likelihood ratio statistic was 12.13 on 3 d.f., $p<0.01$, while keeping time living and dropping age at arrival the likelihood ratio statistic was 8.3 on 4 d.f., $p>0.05$.

When age-group and time living in São Lourenço da Mata were adjusted for each other the association of each of the variables with schistosomiasis remained significant (Table 10). An increased risk for those who had been living in São Lourenco da Mata for 5 or more years was still observed; on the other hand, those aged 20 to 25 years had a

Table 7

Odds ratios, confidence intervals and p-values for schistosomiasis according to the age of migrants from endemic and nonendemic areas arriving in São Lourenço da Mata

\begin{tabular}{|c|c|c|c|}
\hline Variable & Odds ratio & $\begin{array}{l}\text { 95\% Confidence } \\
\text { Interval }\end{array}$ & $\begin{array}{c}\text { p-value } \\
\text { (two-sided) }\end{array}$ \\
\hline
\end{tabular}

AGE AT

ARRIVAL

Migrants from Endemic area

$\begin{array}{lllll}2-4 \text { years } & 1.00^{\mathrm{a}} & & & \\ 5-9 \text { years } & 0.60 & 0.33 & 1.12 & \text { N.S. } \\ 10-14 \text { years } & 0.85 & 0.46 & 1.58 & \text { N.S. } \\ 15-19 \text { years } & 0.67 & 0.34 & 1.31 & \text { N.S. } \\ 20-25 \text { years } & 0.79 & 0.38 & 1.65 & \text { N.S. }\end{array}$

Likelihood ratio statistic $=3.56$, on 4 d.f., $\mathrm{p}>0.10$

\section{Migrants from nonendemic area \\ 2 - 4 years \\ 5 - 9 years \\ $1.00^{\mathrm{a}}$ \\ 10 - 14 years \\ 0.38 \\ 0.42 \\ 0.16 \\ 0.91 \\ 0.18 \\ 1.03 \\ 15 - 19 years \\ 0.16 \\ 0.05 \\ 0.44 \\ 20 - 25 years \\ 0.14 \\ 0.04 \\ 0.47 \\ $\mathrm{p}<0.001$ \\ N.S. \\ $\mathrm{p}<0.001$}

Likelihood ratio statistic $=19.06$, on 4 d.f., $\mathrm{p}<0.001$

areference

p<0.010
Table 8

Odds ratios, confidence intervals and p-values for schistosomiasis according to the time migrants from endemic and nonendemic areas have lived in São Lourenço da Mata

\begin{tabular}{|c|c|c|c|}
\hline Variable & Odds ratio & $\begin{array}{l}\text { 95\% Confidence } \\
\text { Interval }\end{array}$ & $\begin{array}{c}\text { p-value } \\
\text { (two-sided) }\end{array}$ \\
\hline
\end{tabular}

TIME LIVING IN SLM

Migrants from endemic area

Less than 1 year $\quad 1.00^{\mathrm{a}}$

Greater or equal 1

$\begin{array}{lllll}\text { and less than } 5 \text { years } & 0.96 & 0.53 & 1.18 & \text { N.S. }\end{array}$

Greater or equal 5

and less than 10 years $1.58 \quad 0.80 \quad 3.08 \quad$ N.S.

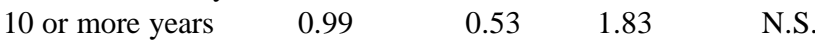

Likelihood ratio statistic $=3.97$, on 3 d.f., $\mathrm{p}>0.10$

Migrants from nonendemic area

Less than 1 year $\quad 1.00^{\mathrm{a}}$

Greater or equal 1

$\begin{array}{lllll}\text { and less than } 5 \text { years } & 0.98 & 0.40 & 2.43 & \text { N.S. }\end{array}$

Greater or equal 5

$\begin{array}{lllll}\text { and less than } 10 \text { years } & 3.60 & 1.27 & 10.17 & \mathrm{p}<0.05\end{array}$

$\begin{array}{lllll}10 \text { or more years } & 3.32 & 1.16 & 9.52 & \mathrm{p}<0.05\end{array}$

Likelihood ratio statistic $=22.89$, on 3 d.f., $\mathrm{p}<0.001$

${ }^{a}$ reference

Table 9

Estimated adjusted odds ratios, confidence intervals and p-values for the association between schistosomiasis, time living in São Lourenço da Mata and age at arrival, for migrants from nonendemic areas

\begin{tabular}{|c|c|c|c|}
\hline Variable & Odds ratio & $\begin{array}{l}\text { 95\% Confidence } \\
\text { Interval }\end{array}$ & $\begin{array}{c}\text { p-value } \\
\text { (two-sided) }\end{array}$ \\
\hline
\end{tabular}

TIME LIVING IN SLM

Less than 1 year

$1.00^{\mathrm{a}}$

Greater or equal 1

and less than 5 years $\quad 0.73$

Greater or equal 5

and less than 10 years 2.3

$\begin{array}{llll}0.73 & 0.27 & 1.96 & \text { N.S. }\end{array}$

10 or more years

2.39

N.S.

Likelihood ratio statistic $=3.97$, on 3 d.f., $p>0.10$

N.S.

\section{AGE-GROUP AT ARRIVAL IN SLM}

$\begin{array}{ll}2-4 \text { years } & 1.00^{\mathrm{a}} \\ 5-9 \text { years } & 0.70 \\ 10-14 \text { years } & 0.99 \\ 15-19 \text { years } & 0.38 \\ 20-25 \text { years } & 0.34\end{array}$

0.26

1.91

N.S.

${ }^{\text {areference }}$
$0.33 \quad 2.95 \quad$ N.S.

$0.11 \quad 1.31 \quad$ N.S.

$0.08 \quad 1.48 \quad$ N.S. 


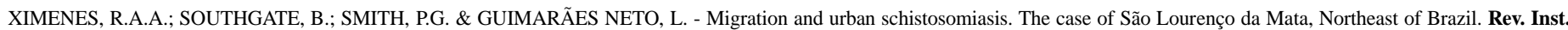
Med. trop. S. Paulo, 42(4): 209-217, 2000.

lower risk of schistosomiasis infection independently of the time they had been living in São Lourenco da Mata.

Table 10

Estimated adjusted odds ratios, confidence intervals and p-values for the association between schistosomiasis, age-group and time living in São

Lourenço da Mata for the group of migrants from noendemic areas

\begin{tabular}{|c|c|c|c|}
\hline Variable & Odds ratio & $\begin{array}{l}\text { 95\% Confidence } \\
\text { Interval }\end{array}$ & $\begin{array}{c}\text { p-value } \\
\text { (two-sided) }\end{array}$ \\
\hline
\end{tabular}

\section{AGE-GROUP}

$\begin{array}{llllc}10-14 \text { years } & 1.00^{\mathrm{a}} & & & \\ 15-19 \text { years } & 1.18 & 0.67 & 2.09 & \text { N.S. } \\ 20-25 \text { years } & 0.34 & 0.17 & 0.68 & \mathrm{p}<0.01\end{array}$

\section{TIME LIVING IN SLM}

Less than 1 year

Greater or equal 1

and less than 5 years $\quad 0.82$

Greater or equal 5

and less than 10 years 3.20

10 or more years

4.40

$1.00^{\mathrm{a}}$

82

2.08

N.S.

$1.10 \quad 9.33 \quad \mathrm{p}<0.05$

areference

We also examined whether the risk of infection varied with residence in a rural endemic area as opposed to those who may have lived in a rural nonendemic area or in an urban (endemic or nonendemic area)(Table $11)$.

\section{Table 11}

Odds ratio, confidence interval and $\mathrm{p}$-value according to the place (rural endemic area $\mathrm{x}$ not rural endemic area) migrants from endemic areas lived

\begin{tabular}{cc}
\hline Variable $\quad$ Odds ratio & $\begin{array}{c}95 \% \text { Confidence } \\
\text { Interval }\end{array}$ \\
\hline
\end{tabular}

Lived in rural

endemic area

Never lived in

rural endemic area

$1.00^{\mathrm{a}}$

Likelihood ratio sta

areference

Those who had never lived in a rural endemic area had a reduced risk of infection but this was not significant.

Within the group of migrants from nonendemic area we evaluated if there was a difference in the risk of infection between those who had lived some time in a rural area with those who had only lived in urban areas (Table 12). Those who had only lived in urban areas experienced a significantly lower risk.
Table 12

Odds ratios, confidence intervals and p-values for schistosomiasis according to the place (rural area $\mathrm{x}$ urban area) migrants from nonendemic area lived

\begin{tabular}{cc}
\hline Variable $\quad$ Odds ratio & $\begin{array}{c}95 \% \text { Confidence } \\
\text { Interval }\end{array}$ \\
\hline
\end{tabular}

\section{Lived in}

rural area

Only lived

in urban area

$1.00^{\mathrm{a}}$

Likelihood ratio statistic $=5.79$, on 1 d.f., $0.01<\mathrm{p}<0.05$

areference

Migrants from endemic and nonendemic areas were compared to the group of natives; migrants from nonendemic areas being categorised according to the length of time they had been living in São Lourenço da Mata (Table 13).

Compared to natives the risk for those who had been living in urban São Lourenço da Mata for less than 5 years was reduced by 3.5 fold while for those who were living in São Lourenço da Mata for more than 5 years the risk was similar to that of the natives.

\section{Table 13}

Odds ratios, confidence intervals and p-values for schistosomiasis according to the place of origin (migrants from nonendemic areas categorized according to the length of time they lived in São Lourenço da Mata)

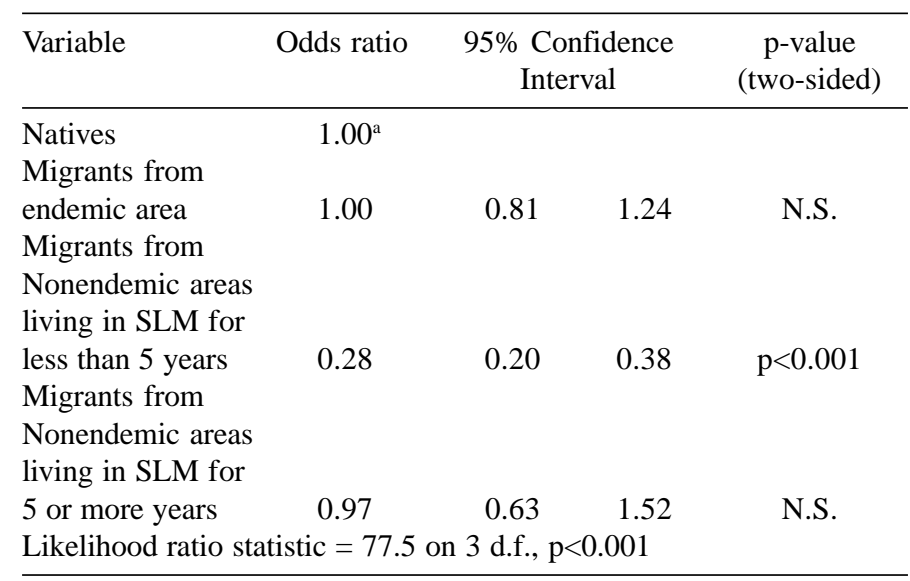

${ }^{a}$ reference

\section{DISCUSSION}

Migration still occurs in large scale in Brazil, between and within areas. During the eighties approximately 2.2 millions individuals moved to the Northeast, mainly to Pernambuco, Bahia and Maranhao, and 2.7 millions left that region ${ }^{29}$. The link between population movement and schistosomiasis has been documented. Therefore we would like just to call the attention to some peculiar features of migration and the urbanisation of schistosomiasis in a specific area. 
Among natives there was an association between sex, treatment for schistosomiasis and the infection. The interpretation of the enhancement of risk for those who had not been treated is not straightforward. In the control programme antischistosomiasis treatment was not targeted to the positive individuals. It is possible that the proportion of infected individuals in the 2 groups (treated and untreated) was the same before treatment. If this was the case, then, the reduction in risk for those who had taken treatment (oxamniquine) would mean that at least a proportion of them was not reinfected after treatment, for example, due to acquired immunity or to changes in the water contact behaviour. If, on the other hand, the proportion of infected individuals in the two groups was different before treatment, the interpretation of the impact of the antischistosomiasis therapy would be difficult.

Concerning the migrants the results were analysed according to whether the individuals had or not lived in an endemic area.

The lower risk of infection found for those who had never lived in an endemic area is not surprising as they had not been exposed to transmission sites before moving to São Lourenço da Mata. Moreover, the association between schistosomiasis and age just for this group of migrants, with those aged 20 to 25 years showing a significantly lower risk of infection, suggests that those subjects may have arrived in São Lourenço da Mata at an age in which water contact activities are less frequent.

For both groups of migrants there was no association between infection and treatment for schistosomiasis. It may be due to the fact that the schistosomiasis control programme was not adequately implemented in this area: the interval between consecutive treatments was quite irregular and there were changes in the guidelines of the programme.

For those migrants who had lived in an endemic area, neither age at arrival nor time living in São Lourenço da Mata were significantly associated with schistosomiasis. The absence of association, especially with the length of residence in São Lourenço da Mata, suggests that these subjects may have already been infected before emigrating. It is also conceivable, but less likely, that these individuals got infected, while visiting their place of origin, after having moved to São Lourenço da Mata. The opposite finding for those who had lived in nonendemic areas may be taken as evidence that transmission is occurring in the urban São Lourenço da Mata. This idea is also supported by the malacological investigation conducted, which found infected snails in snail breeding sites in the urban area ${ }^{36}$. If it is not in the city itself it is in a nearby site attended by the local population.

When the relation between schistosomiasis and time living and age at arrival was examined, adjusting for the effect of each other, only the association with time living remained statistically significant, suggesting that, in the group of migrants from nonendemic area, time living is more closely related to the infection than age at arrival. On the other hand, the mutual adjustement of age-group and time living showed that the association between age-group and schistosomiasis occurs independently of the effect of time living and vice-versa. The reduced risk of schistosomiasis for those aged 10 to 25 years was not observed either in the group of natives or in the group of migrants from endemic areas. For some reason, which is not clear, they were, as a group, less exposed to transmission sites in the new environment. Either their behaviour in relation to water contact was different or the water contact they had was not in transmission sites.

Within the group of migrants from nonendemmic area, those who had only lived in urban areas experienced a significantly lower risk of schistosomiasis. It is not likely that those who lived in rural areas would have performed water contact activities in their place of origin, for rural nonendemic areas in the state of Pernambuco are usually dry areas. Having lived in rural or urban area could only be a proxy for other(s) factor(s), like the standard of living.

Population movements may be focused in different ways. When considering the determinants of migration a subtle difference exists between the cause of migratory movements and an individual migrant's specific motivation to move. It is likely that the cause of migration lies in socio-economic conditions which determine the movement of a specific group or class ${ }^{32}$. Naturally, individual variability will exist within the group, but these characteristics cannot be taken as the real causes themselves. There is, at first, a social determination of the movement of a group, but then objective and subjective reasons will further influence the decision of which members of the group stay or leave. In "zona da mata" the sugar agro-industry and in "zona do agreste" the increase in the area used for cattle grazing led to a deterioration in the living conditions of the agricultural workers due to the very low wages offered and an inability to grow their own crops; many had no choice but to move.

In the Northeast, between 1950 and 1960, agricultural activities absorbed $52 \%$ of the employment growth, industry $6.0 \%$ and commerce 42\%. Between 1970 and 1980 the figures had changed with agricultural activities absorbing only $19 \%$ of the employment expansion, industry $30 \%$ and commerce $51 \%{ }^{14}$. The type of economic development adopted is substituting the poverty of those excluded from the entrepreneurial type of production by the poverty of those integrated to it. Moreover, even with the creation and expansion of employment in the formal sector of the economy, the importance of the informal sector cannot be ignored. It is estimated that in urban areas the informal sector accounts for between $30 \%$ and $45 \%$ of the economically active population ${ }^{13}$. The informal sector together with the poor working relations often occurring in the units belonging to the formal sector produce a picture characterised by underemployment and underpayment ${ }^{12}$. Urban underemployment rates in the region are as high today as they were 30 years ago when exportled cane-sugar activities were almost the only source of income and employment in the Northeast ${ }^{33}$.

The type of urbanisation that is taking place in São Lourenço da Mata, concentrating the population in small areas, with very low living standards and poor sanitary conditions make possible local transmission of schistosomiasis. The percentage of individuals with an insufficient income, defined as the percentage of the population which earns less than 0.5 minimum wages per member of the family, reaches 67.23 in this "municipio" 28 . Water supply and sanitary conditions are unevenly provided. Only $55.3 \%$ and $24.1 \%$ of the population have access to, respectively, piped water inside the house and adequate excreta collection (either connection with the city sewage system or excreta collected in pit or tank $)^{28}$. The intermediate host finds suitable breeding places in drains, canals, sewers and other water collections in urban areas in which 
the population may be exposed to the cercariae. It is not surprising that the natives and those migrants who come from endemic areas (for schistosomiasis) have a similar risk of infection. On the other hand, the risk of infection of migrants from nonendemic area seems to be related with the time elapsed since their arrival in São Lourenço da Mata. After 5 years living in that urban area the risk of being infected is similar to that of natives.

\section{RESUMO}

\section{Migração e esquistossomose urbana. O caso de São Lourenço da Mata, nordeste do Brasil}

Um estudo de caso-controle de base populacional foi desenvolvido para estudar a associação entre migração, urbanização e esquistossomose na Região Metropolitana do Recife, Nordeste do Brasil. Foram selecionados 1022 casos e 994 controles no grupo etário de 10 a 25 anos. Observou-se que os nativos e os migrantes que são provenientes de áreas endêmicas tem um risco semelhante de infecção. Por outro lado, o risco de infecção em migrantes não originários de áreas endêmicas parece estar relacionado com o tempo decorrido desde sua chegada em São Lourenço da Mata; aqueles que estão morando nessa área urbana por um período igual ou superior a cinco anos tem um risco de infeção semelhante ao dos nativos.

As mudanças na indústria agro-açucareira na Zona da Mata e a expansão das áreas de criação de gado no Agreste impeliram os trabalhadores rurais a se deslocar para vilarejos e cidades. O padrão de urbanização que ocorreu em São Loureço da Mata criou as condições propícias para que se estabelecessem focos de transmissão.

\section{ACKNOWLEDGEMENTS}

Financial support for this investigation was generously provided by the Social and Economic Research Steering Committee, Special Programme for Research and Training in Tropical Diseases (TDR), World Health Organisation (UNDP/World Bank/WHO).

I grateful acknowledge a grant from Conselho Nacional de Desenvolvimento Cientifico e Tecnologico - CNPq - Brazil.

\section{REFERENCES}

1. ANDRADE, B., coord. - Migrações sazonais no nordeste (relatório de pesquisas). Recife, SUDENE,UFPE, 1981.

2. ANDRADE, M.C. - A terra e o homem no nordeste. São Paulo, Brasiliense, 1963.

3. BARBOSA, C.S.; SILVA, B.C. \& BARBOSA, F.S. - Schistosomiasis: reproduction and expansion of the endemic region in Brazil. Rev. Saúde públ. (S. Paulo), 30: 609616, 1996.

4. BELlA, H.; MARSHALL, T.F.C.; OMER, A.H.S. et al. - Migrant workers and schistosomiasis in the Gezira, Sudan. Trans. roy. Soc. trop. Med. Hyg., 74: 36-39, 1980.

5. BINA, J.C. - A expansão da esquistossomose mansoni no Brasil: fatores determinantes e sugestões para o seu controle. Rev. Med. Bahia, 22: 86-100, 1976.

6. CAMARGO, S. - The impact of the country development in the expansion of schistosomiasis. Rev. Inst. Med. trop. S. Paulo, 22(suppl. 4): 2-4, 1980.
7. CARVALHO, O.S.; MASSARA, C.L.; ROCHA, R.S. et al. - Esquistossomose mansoni no sudoeste do estado de Minas Gerais. Rev. Saúde públ. (S. Paulo), 23: 341-344, 1989.

8. CHANDIWANA, S.R. - Human bilharziasis in a peri-urban area in Zimbabwe with special reference to its relationship to malnutrition in schoolchildren. Cent. Afr. J. Med. 29: 23-26, 1986.

9. COUTINHO, J.O. - Geografia médica das protozooses. In: LACAZ, C.S.; BARUZZI, R.G. \& SIQUEIRA, W. Introdução à geografia médica do Brasil. São Paulo, Ed. Universidade São Paulo, 1972.

10. DIAS, L.C.S.; MARÇAL JR., O. \& GLASSER, C.M. - Control of schistosomiasis transmission. Mem. Inst. Oswaldo Cruz, 90: 285-288, 1995.

11. GRYSEELS, B. \& NGIMBI, N.P. - Further observations on the urban Schistosoma mansoni focus in Kinshasa, Zaire. Ann. Soc. belge Med. trop., 63: 341-346, 1983.

12. GUIMARÃES, L. - Emprego em Pernambuco: notas sobre experiência recente. Rev. pernambuc. Desenvolv., 10: 3-21, 1983.

13. GUIMARÃES, L. \& SOUZA, A.V. - A dinâmica do mercado de trabalho urbano no nordeste. In: CARVALHO, I.M.M. \& HAGUETE, T.M.T., coord. Trabalho e condições de vida no nordeste brasileiro. São Paulo, Hucitec, 1984.

14. GUIMARÃES, L. - O processo de integração do nodeste. In: SALM, C., coord. O mercado de trabalho brasileiro. Rio de Janeiro, IEI/UFRJ, 1987.

15. JIANG, Z.; QING-SI, Z.; XIAN-FENG, W. et al. - Analysis of social factors and human behaviour attributed to family distribution of schistosomiasis japonica cases. Southeast Asian J. trop. Med. publ. Hlth., 28: 285-290, 1997.

16. KATO, K. \& MIURA, M. - Comparative examinations. Jap. J. Parasit., 3: 35, 1954

17. KATZ, N.; CHAVES, A. \& PELLEGRINO, J. - A simple device for quantitative stool thick-smear technique in schistosomiasis mansoni. Rev. Inst. Med. trop. S. Paulo, 14: $397-400,1972$

18. KLOOS, H. - Water resources development and schistosomiasis ecology in the Awash Valley, Ethiopia. Soc. Sci. Med., 20: 609-625, 1985.

19. KLOOS, H.; LO, C.T.; BIRRIE, H. et al. - Schistosomiasis in Ethiopia. Soc. Sci. Med., 26: $803-827,1988$

20. LAMBERTUCCI, J.R.; ROCHA, R.S.; CARVALHO, O.S. et al. - A esquistossomose mansoni em Minas Gerais. Rev. Soc. bras. Med. trop., 20: 47-52, 1987.

21. MACHADO, P.A.; GUERRA, J.C. \& ABREU, L.G.S. - Planorbídeos no município de Campinas. Rev. Inst. Adolfo Lutz, 15: 168-172, 1955.

22. MACHADO, P.A. - Brazil's special schistosomiasis control program. Bull. Pan Amer. Hlth. Org., 13: 33-45, 1979.

23. MARQUES, R.J. - A propósito da chamada fase toxêmica da esquistossomose mansônica. An. Fac. Med. Univ. Recife, 17: 243-256, 1957.

24. MEUNIER, D.M.Y.; GEORGES, M.C. \& GEORGES, A.J. - Bilan des parasitoses intestinales de l'adulte dans un milieu urbain de la république centrafricaine. Bull. Soc. Path. éxot., 77: 333-343, 1984.

25. MOURA, H.A \& COELHO, J.O.M. - Migrações para as grandes cidades do nordeste: intensidade e características demográficas. In: MOURA, H.A., coord. Migração interna. Textos selecionados. Fortaleza, Banco do Nordeste do Brasil, 1980. v.I.

26. ODONGO-AGINYA, E.I. \& MUGISA, C. - The prevalence of Schistosoma mansoni in migrants from endemic areas living in the Entebbe Peninsula, Uganda. East Afr. med. J., 64: 571-579, 1987. 
27. PEREIRA, G. - Esquistossomose urbana. Recife, Editora Universitaria, 1981.

28. PROGRAMA DAS NACÕES UNIDAS PARA O DESENVOLVIMENTO Desenvolvimento humano e condições de vida: indicadores brasileiros. Atlas de Desenvolvimento Humano, CD ROM, 1998.

29. RIBEIRO, J.T. - Caracterização sociodemográfica da migração na década de 80 por grandes regiões brasileiras. Cadern. Estud. soc., 12: 357-382, 1996.

30. ROBERT, C.F.; BOUVIER, S. \& ROUGEMONT, A. - Epidemiology of schistosomiasis in the riverine population of Lagdo Lake, Northern Cameroon: mixed infections and ethnic factors. Trop. Med. Parasit., 40: 153-158, 1989.

31. SARDA, R.K.; SIMONSEN, P.E. \& MAHIKWANO, L.F. - Urban transmission of urinary schistosomiasis in Dar es Salaam, Tanzania. Acta trop. (Basel), 42: 71-78, 1985.

32. SINGER, P. - Dominação e desigualdade: estrutura de classe e repartição de renda no Brasil. Rio de Janeiro, Paz e Terra, 1981.
33. SOUZA, A.V.; GUIMARÃES, L. \& ARAUJO, T.P. - Employment implications of informa sector policies. A case study of Greater Recife. Int. Labour Rev., 127: 243-258, 1988

34. TRAORE, M. - Schistosomiasis in the Selingue dam area: the integrated approach. Trop. Med. Parasit., 40: 228-231, 1989.

35. WORLD HEALTH ORGANIZATION - The control of schistosomiasis. Wld. Hlth. Org techn. Rep. Ser., (728), 1985.

36. XIMENES, R.A.A. - Urbanization of schistosomiasis: Metropolitan Region of Recife. (Social causation of schistosomiasis in the age-group 10-25 years in the urban area of the "Distrito" of São Lourenço da Mata). London, 1991. (PhD Thesis, London School of Hygiene and Tropical Medicine/University of London).

Received: 09 December 1999

Accepted: 13 March 2000 